\title{
LITÍGIO E NEGOCIAÇÃO DO PATRIMÔNIO NO DIREITO: A JUDICIALIZAÇÃO DO CASO DO EDIFÍ́CIO DO ANTIGO CINE PALÁCIO DE JOINVILLE
}

\section{LITIGATION AND NEGOTIATION OF HERITAGE IN THE LAW: THE JUDICIALIZATION OF THE CASE OF THE BUILDING OF THE FORMER CINE PALÁCIO OF JOINVILLE}

\author{
Maria Bernardete Ramos Flores ${ }^{1}$ \\ Christiane Heloisa Kalb²
}

\section{Resumo}

O intento deste estudo é analisar como o Direito age no campo do patrimônio, através de um caso emblemático, que é o caso da judicialização do antigo Cine Palácio de Joinville. O fato que ensejou o processo foi a não conservação do objeto de estudo deste caso, portanto, demonstraremos suas transformações e o que decorreu judicialmente entre as partes envolvidas. Passados alguns anos da patrimonialização de um espaço que inicialmente era um cine-teatro, o locatário alterou estética e arquitetonicamente o edifício sem requerer autorização ao órgão de preservação local. Assim, não houve outra saída à municipalidade a não ser ajuizar processo cível para averiguar os possíveis danos àquele bem tombado. Durante a análise tanto do processo administrativo quanto do judicial, houve o surgimento de algumas questões. Essas problemáticas dizem respeito ao uso, ou melhor, aos diversos usos que se fizeram do espaço do Cine Palácio e a uma suposta autenticidade desses usos em face dos discursos de grupos de poder engendrados nos processos. Desta forma, por meio de um recorte a tese de doutoramento em Ciências Humanas, em que se pesquisou as políticas públicas de preservação do patrimônio cultural da cidade de Joinville, elencamos neste estudo questionar como a contemporaneidade vem respondendo a essas problemáticas envolvendo o instituto do tombamento, o Direito e o campo do patrimônio.

Palavras-chave: patrimônio cultural, judicialização, Joinville, cinema de rua, tombamento.

\begin{abstract}
The purpose of this study is to analyze how law acts in the field of cultural heritage, through an emblematic case, which is the case of the judicialization of the former Cine Palacio of Joinville. The fact that triggered the process was the non-conservation of the object of study of this case, therefore, we will demonstrate its transformations and what happened judicially between the parties involved. After some years of patrimonialisation of a space that initially was a cinetheater, the renter aesthetically and architecturally altered the building without requiring authorization to the local organ of preservation. Thus, there was no other way out to the municipality other than to file a civil case to ascertain the possible damages to that asset. During the analysis of both the administrative and the judicial process, there were some issues. These problems are related to the use, or rather to the various uses made of the space of the Cine Palacio and to a supposed authenticity of these uses in the face of the discourses of power groups engendered in the processes. Thus, by means of a clipping the doctoral thesis in Human

\footnotetext{
${ }^{1}$ Pós-doutora pela Universidade Nova de Lisboa/University of Maryland e pela Universidad de San Martín. Professora titular do Departamento de História da UFSC - Universidade Federal de Santa Catarina. E-mail: mberna@gmail.com

2 Professora Doutora - Departamento de Direito - CESUSC - Complexo de Ensino Superior de Santa Catarinal. Doutora em Ciências Humanas, PPGICH, UFSC, Florianópolis-SC. E-mail: christianekalb@hotmail.com
} 
Sciences, in which the public policies for the preservation of the cultural heritage of the city of Joinville were researched, we focus on this study to question how contemporaneity has been responding to these problems involving the institute of patrimonialisation, the Law and the field of the cultural heritage.

Keywords: cultural heritage, judicialization, Joinville, street cinema, patrimonialisation.

\section{INTRODUÇÃO}

Quando se pensa em cultura e, por conseguinte, em como preservar bens culturais, não se está adstrito à ideia de sobrevivência das criações humanas. E o século XX foi um período marcado por intensas mudanças em virtude do rápido progresso tecnológico, o que por um lado incrementou as invenções humanas e, por outro, deixou ruir tecnologias defasadas. Nesse contexto, a preservação dos patrimônios, criados ou não pelo homem, pode estar permeada pelo espírito de romantismo e nostalgia, se considerar as correntes urbanistas dos culturalistas, motivadas pelo interesse das pessoas em encontrarem um passado marcado por estabilidade e prosperidade. No caso brasileiro, o interesse pelo passado num determinado momento foi uma forma de marcar o nacionalismo a partir da retomada do período do barroco mineiro por meio dos ideais modernistas. Outros entendem a preservação dos bens culturais como uma ideia elitista, se pautada no que os urbanistas progressistas vão trazer de soluções para as cidades industriais, nas quais a manutenção de certas tradições constitui uma justificativa para a conservação do status quo de determinados setores sociais.

O patrimônio cultural de uma sociedade, mais que estabelecer limites, coleções e escolhas a partir de discursos, tem sua importância arraigada no sentido de questionar de onde viemos e para onde vamos. O patrimônio é tingido de valores numa dada época, num certo momento histórico e, portanto, é uma construção social, diacrítica, normalmente pensada por uma elite que muitas vezes acaba por excluir certos grupos, geralmente minoritários. Todavia, essas elites, representadas por instituições de preservação, deveriam servir aos cidadãos ao invés de servir a grupos de interesses políticos e econômicos. A Carta Magna do Estado Brasileiro, que em seu artigo 216 dispõe sobre o patrimônio cultural brasileiro, o definiu de modo a incluir os bens culturais de natureza material e imaterial, portanto, o que o constitui seriam "os bens de natureza material e imaterial que tomados individualmente ou em conjunto são portadores de referência à identidade, à ação, à memória dos diferentes grupos formadores da sociedade brasileira" (BRASIL, 1988). 
Pensar, então, o patrimônio a partir da identidade cultural como o passado de uma etnia (ou grupo social) é uma maneira de demonstrar o reconhecimento à ideia comunitária, isso quando o próprio grupo detentor de determinado patrimônio se reconhece perante ele. Assim, os sistemas de símbolos que cada grupo de pessoas experimenta subjetivamente como sua identidade podem ser chamados de cultura, "uma vez que eles [os patrimônios] materializam uma teia de categorias de pensamento por meio das quais nos percebemos individual e coletivamente" (GONÇALVES, 2007, p. 29). Para este estudo, o conceito de tombamento que se utilizará será a forma institucionalizada de proteger os bens culturais, iniciados em 1937, através do Decreto de n. 25 e que se espraiou para outras legislações estaduais e municipais, abrangendo todo o patrimônio brasileiro. Este decreto e as leis locais que protegem o patrimônio cultural se basearam inicialmente nas cartas patrimoniais europeias - Cartas de Atenas e de $V_{\text {eneza }}{ }^{3}$-, bem como outras Convenções e Recomendações ${ }^{4}$ que também foram inseridas no ordenamento jurídico do país.

\footnotetext{
${ }^{3}$ Os encontros internacionais, chamados de Congressos Internacionais de Arquitetura Moderna (CIAM), vieram a ocorrer a partir de 1928. Em 1933, o encontro foi realizado em Atenas, quando aconteceu a primeira Conferência Internacional sobre a conservação artística e histórica dos monumentos, com participantes exclusivamente europeus. Na oportunidade foi publicada a 1a Carta de Atenas (1933), que estabelecia normas para se preservar os monumentos históricos frente à expansão das cidades, bem como metodologias de restauração, conservação e utilização desses monumentos. O tema do Congresso de Atenas era a "cidade funcional", que vinha propor uma nova maneira de viver, organizada por meio de um estatuto de solo para atender quatro necessidades humanas básicas, a saber: a habitação, o lazer, o trabalho e a circulação. Além das quatro necessidades, por sugestão da delegação italiana, foi introduzida uma seção voltada ao "patrimônio histórico" das cidades (1933, p. 25). É importante frisar que o patrimônio histórico não era o foco principal desta carta patrimonial, tanto que a seção está localizada bem ao final do documento, no entanto, já se via um lapso de preocupação nesse sentido. Somente em 1964, com a 2a edição da Conferência Internacional de Arquitetos e Técnicos de Monumentos Históricos, realizada em Veneza, contando com a presença de representantes mexicanos, peruanos e da Tunísia, foi publicada a Carta de Veneza, trazendo indícios de mudanças no tratamento dos bens culturais. O pósSegunda Guerra veio trazer mudanças significativas aos debates sobre patrimônio em razão do conflito bélico que destruiu muitos exemplares de bens culturais. Estes documentos escritos por arquitetos, engenheiros e intelectuais da época exprimiam as principais preocupações e os discursos oficiais sobre o crescimento desordenado das cidades e a necessidade de renovação de algumas áreas já em deterioração naquele período. Eles colocaram questões que escreveram no traçado e na arquitetura da cidade, suas demarcações e identidade de determinados lugares circunscritas de particularidades geográficas, econômicas e políticas, ainda que a ideia de conservação não tenha sido unanimemente aceita desde o início das discussões entre os intelectuais. A Carta de Veneza tratou, em seu conteúdo, especialmente sobre o interesse universal de proteção dos monumentos, deixando a concepção de musealização de lado nas áreas urbanas, contemplando uma função de utilidade social, reconhecendo que os bens culturais podem ter uma função diferente das quais foram concebidos na origem de suas construções.

${ }^{4}$ Vejamos: a Recomendação que define os princípios internacionais que deverão aplicar-se às escavações arqueológicas, ocorrida na Conferência Geral, em Nova Délhi, em 1956; a Recomendação relativa à proteção da beleza e do caráter dos lugares e paisagens, assinada na Conferência Geral de Paris, em 1962; a Recomendação sobre medidas encaminhadas para proibir e impedir a exportação, importação e
} 
Quando se fala de uma determinada coletividade e aqui estamos a tratar das políticas públicas em defesa do patrimônio cultural da cidade de Joinville, através de um recorte que se fez de uma tese de doutoramento em Ciências Humanas, desenvolvido na UFSC, se percebe que esta herança cultural ganhou novos contornos particularmente após os anos 2000. Foi um momento em que se concretizaram as primeiras ações efetivas em prol da patrimonialização de bens culturais da cidade norte-catarinense. Foi também nos anos 2000 que se desenrolou o processo de tombamento em nível municipal do antigo espaço cultural - o Theatro Nicodemus (fig. 1). Este teatro, que mais tarde se transformou no Cine Palácio, ganhou novos usos na década de 1990, pois foi ressignificado como espaço de culto, a partir de sua locação pela Igreja Universal do Reino de Deus. Abaixo se vê uma imagem da época da inauguração do Theatro Nicodemus, quando o centro da cidade ainda não era pavimentado e muito pouco habitado.

\section{Figura 1: Cine Palácio. Notam-se as inscrições "1917 Theatro Nicodemus" e o desenho de uma lira no centro, representando a música}

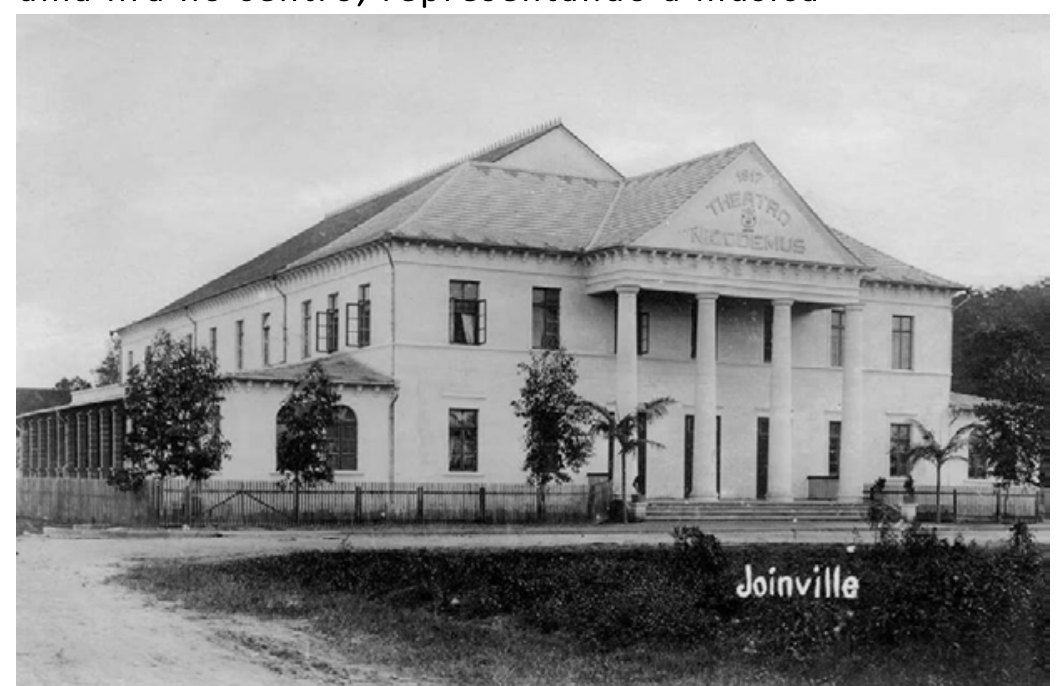

Fonte: Arquivo Histórico de Joinville. Envelope: Sociedades, cinemas, teatros e clubes, n. 144, 2015.

Passados alguns anos da patrimonialização do espaço, quando o cine-teatro já estava tombado pela municipalidade, o locatário começou a realizar obras ditas emergenciais na sua estrutura, contudo, a igreja não se precaveu. Alterou estética e arquitetonicamente o edifício

transferência da propriedade ilícita dos bens culturais e a Recomendação concernente à conservação dos bens culturais que a execução de obras públicas ou privadas pode por em perigo, ambas da Conferência Geral de Paris, em 1968; a Recomendação sobre a proteção, em âmbito nacional, do patrimônio natural e cultural, da Conferência Geral de Paris, em 1972, e a Recomendação relativa à salvaguarda dos conjuntos históricos e sua função na vida contemporânea, na Conferência Geral de Nairóbi, em 1976. Todas foram ratificadas pelo governo brasileiro. No entanto, houve outras que não foram acrescidas, como é o caso da Convenção relativa à proteção do patrimônio cultual subaquático e da Convenção da UNESCO de 2001, que não foram adicionadas à legislação brasileira (Disponível em: portal.iphan.gov.br/uploads/ckfinder/.../Recomendacao\%20de\%20Paris\%201962.pdf ). 
sem requerer autorização ao órgão de preservação local. Assim, não houve outra saída à municipalidade a não ser ajuizar processo cível para averiguar os possíveis danos àquele bem tombado. Durante a análise tanto do processo administrativo quanto do judicial, houve o surgimento de algumas questões. Essas problemáticas dizem respeito ao uso, ou melhor, aos diversos usos que se fizeram do espaço do Cine Palácio e a uma suposta autenticidade desses usos em face dos discursos de grupos de poder engendrados nos processos. Mais do que isso, questionar como a contemporaneidade vem respondendo a essas problemáticas envolvendo o instituto do tombamento, o Direito e o campo do patrimônio é o objetivo principal deste estudo. Portanto, nosso intento é mostrar como o Direito age no campo do patrimônio, através de um caso emblemático, que é o caso da judicialização do antigo Cine Palácio de Joinville.

O processo de tombamento em nível municipal do edifício do Cine Palácio teve início oficialmente em 17 de abril de $2003^{5}$, tendo como proprietária do prédio, na época do tombamento, a Empresa de Cinemas Arcoíris Ltda. No entanto, para se concretizar tal ato foi necessário bem mais do que a decisão favorável pela maioria da Comissão de Patrimônio de Joinville - Comphaan. Do engajamento da universidade à força da mídia impressa, até a Fundação Cultural de Joinville - FCJ, por meio da Comphaan, a cidade viu surgir um caso paradigmático de patrimônio, no qual não poderia ficar silente.

Do momento do tombamento, em 2003, até o ano corrente de 2017 já se vão 14 anos desde que a Fundação Cultural de Joinville, representante até dezembro de 2016 da agenda da cultura na municipalidade (extinta em dezembro de 2016, sendo substituída pela Secretaria de Cultura e Turismo - Secult), tendo como defensores os Procuradores municipais, de um lado, e os proprietários (Empresa de Cinemas Arcoíris Ltda., sucessora da Empresa Cinematográfica Van Biene S/A, representada por Mario Leopoldo dos Santos, empresário - proprietária; e Igreja Universal do Reino de Deus (IURD), representada pelo preposto Emerson Carlos de Oliveira, bispo evangélico - locatária) do edifício do antigo Cine Palácio, de outro, vêm entrando em conflitos e embates técnico-jurídicos relacionados à preservação do prédio tombado. Descrever e problematizar esse enredo jurídico é o objetivo deste estudo.

\section{PREDECESSORES DO ENREDO JUDICIAL}

A judicialização do caso do edifício do antigo Cine Palácio é uma demanda que envolveu a discussão de uma suposta autenticidade ou originalidade material relacionada à

\footnotetext{
${ }^{5}$ Número do Processo de tombamento FCJ. CPC. 2002-001 - Inscrição Imobiliária é 13.20.24.52.0485.
} 
monumentalidade arquitetônica do bem patrimonializado que se perdeu. E tal situação traz a ideia do mito da originalidade como alegoria, no qual a cidade está dentro de um espaço simbiótico em que o poder dos agentes do campo do patrimônio age com a determinação de integrar culturalmente os habitantes numa identidade coletiva, sob a tentativa de reconstrução de uma verossimilhança histórica que possui valor de marca da dinâmica de determinada cidade frente às outras. Richard Handler (1985) esclarece que a ideia de autenticidade está ancorada ao moderno ocidente e à emergência do individualismo, especialmente associada à possibilidade de uma coletividade imaginada como nacional ou ligada à cidade (Anderson, 2008).

A ideia de que talvez alguns valores, antes legítimos e importantes à primeira vista, possam ter se perdido não se trata de uma insinuação. A autenticidade não poderia limitar-se à questão estética, pois ultrapassa esse valor. Os valores atribuídos ao cine-teatro, de fundo arquitetônico, histórico e, principalmente, cultural, quando de seu tombamento em 2003, foram se modificando com novos contextos de entorno e de uso que se fizeram especialmente no início dos anos 2000. Afinal, constituir o edifício do antigo Cine Palácio como patrimônio da cidade é uma construção narrativa, chancelada pelos pareceres técnicos que instruíram o processo de tombamento. Apesar das estratégias seguidas não terem salvaguardado arquitetonicamente o edifício e até o momento não terem propriamente o recuperado por meio de restauração, as justificativas concebidas pelos membros da Comphaan foram em prol de seu tombamento e de sua preservação.

Poderemos averiguar através desse caso emblemático, tanto no processo administrativo de tombamento e como na judicialização do caso que as tensões, os embates entre grupos e os jogos de poder engendrados nos processos de preservação do patrimônio cultural de Joinville iniciados principalmente a partir da década de 1980 (quando fundadas a Comphaan e depois a FCJ) são muito mais complexos do que inicialmente se mostram. Quando se analisa um processo específico, como será este caso emblemático do edifício do Cine Palácio, antigo Theatro Nicodemus, tem-se uma visão mais ampla dos aspectos pormenorizados que ocorrem nos meandros de um processo administrativo e também a partir da sua judicialização. São acusações, defesas e réplicas constantes sem realmente se encontrar um culpado para o fato do último exemplar de cinema de rua de Joinville, representado num prédio, estar onde e como está hoje.

Em novembro de 2003, assim sete meses após o tombamento do imóvel pela municipalidade, houve a juntada, durante uma reunião da Comissão de Patrimônio - colegiado 
que detém o poder de escolha sobre os tombamentos e liberações da cidade - de um parecer técnico vindo da Prefeitura, encaminhado por uma Comissão Especial, que avaliou a importância do edifício no âmbito patrimonial, no qual constavam alterações não autorizadas no imóvel nem pela Prefeitura, nem pela Fundação Cultural de Joinville, órgãos competentes na época pela fiscalização do bem tombado. Isso, conforme afirmamos acima em poucos meses desde a homologação que declarou o prédio patrimônio cultural da cidade por meio do tombamento. Tais mudanças se referiam às substituições de madeiramento de cobertura, de piso, retirada de reboco interno e corte nas paredes no piso superior, portanto, se tratavam de modificações no interior do espaço, apesar de que outras alterações ocorridas desde a sua inauguração em 1917 foram tema de discussão processual. Durante a reunião da Comphaan ficou definido que tais alterações desautorizadas seriam encaminhadas ao Ministério Público para que fossem tomadas as devidas providências [Ata Comphaan, 26 nov. 2003] e, se fosse o caso, instaurar o devido Inquérito Cível/Criminal.

Desse parecer, apresentado no fim de 2003 até abril de 2004, houve a juntada de seis boletins de fiscalização, um ato de embargo e duas multas, tudo implementado pela Prefeitura e juntado aos autos do tombamento, todos com intento de parar as obras iniciadas sem autorização do órgão competente. Mas nem por isso o proprietário e o locatário do edifício cessaram as atividades. Durante a reunião da Comphaan de 25 de maio de 2004, Miraci Deretti, presidente da Fundação na época, informou que os responsáveis pelo edifício do antigo Cine Palácio continuaram a fazer intervenções sem qualquer liberação de alvará. Ele afirmou ainda que a Prefeitura já havia feito intervenção, embargando a obra e multando os responsáveis, no entanto, as multas ainda não tinham sido pagas. O presidente explicou ainda que "em acordo feito com a Prefeitura, os responsáveis pela Igreja comprometeram-se em cobrir o telhado e providenciar os documentos e ações necessárias para legalizar a obra. Porém, este acordo foi quebrado e a reforma continuou mesmo sem o alvará" [Ata Comphaan, 25 mai. 2004].

Assim, não havendo mais solução amigável para o caso, e mesmo após tais procedimentos administrativos (boletins, embargos e aplicação de multa), em julho de 2004 a FCJ realizou vistoria no local e fez diversas considerações ao locatário, para que restaurasse adequadamente o prédio. Nesse ínterim, a Prefeitura de Joinville, por meio do procedimento judicial do Procurador municipal Luiz Bernando West Costa, ajuizou ação de Nunciação de Obra Nova cominada com demolitória e antecipação de tutela de autos no 0021739 62.2006.8.24.0038, perante a Justiça Estadual de Santa Catarina, na comarca de Joinville, em 
face da Igreja Universal do Reino de Deus e da Empresa de Cinemas Arcoíris Ltda., locatária e legítima proprietária, respectivamente responsáveis pelo imóvel (FCJ, 2002, p. 299-307).

\section{A CELEUMA EM DEBATE}

O edifício do antigo Cine Palácio foi descaracterizado em sua infraestrutura física mesmo após o seu tombamento efetivado e homologado por Decreto Municipal, motivo pelo qual houve o ajuizamento de ação cível perante à Justiça, em 24 de junho de 2004. Os pedidos da Prefeitura eram para que ambas as rés (Igreja Universal do Reino de Deus e Empresa Cinema Arcoíris Ltda.) parassem com as obras, que ainda estavam em andamento, até que houvesse a demolição do que já havia sido construído indevidamente e se autorizasse corretamente o restauro. Tais pedidos foram feitos em sede de urgência, por isso a antecipação de tutela, visto o perigo que o edifício do antigo Cine Palácio vinha suportando.

Logo que citada, a Universal contestou a ação e agravou (TJ/SC, 2016, p. 70) o pedido liminar, alegando que as obras ${ }^{6}$ eram emergenciais com o único intuito de evitar o desabamento e que, consequentemente, estariam preservando o bem material em si. E ainda afirmaram que ao iniciar as obras enviaram e-mails ao IPPUJ - Instituto de Pesquisa e Planejamento Urbano de Joinville, mas não detiveram nenhuma resposta e que, com a falta de afirmativa ou negativa de continuidade das obras, receberam uma autorização extraoficial de um funcionário da Prefeitura, que disse ter verbalmente autorizado o serviço (TJ/SC, 2016, p. 87).

Na petição de contestação, os advogados da Igreja Universal não indicam o nome do suposto funcionário público que teria autorizado a continuidade das obras, ainda que sem nenhum alvará regular, o que francamente gera desconfiança frente à afirmação da parte ré. Além disso, em sede de defesa, a Universal juntou cópia do contrato de prestação de serviço, com a empresa Omnicon Engenharia Ltda., no valor total de $\mathrm{R} \$ 110$ mil, em que constavam as obras de reforma geral que seriam realizadas no prédio. No documento, de fls. 116 dos autos, não consta a expressão restauro em nenhuma passagem, apenas se veem expressões como reforma e obra. No entanto, às fls. 211 dos autos, a Universal juntou documento que enviou ao IPHAN questionando-o sobre o procedimento a ser tomado quanto à restauração do reboco das paredes do edifício. "O IPHAN enviou em resposta, por email, uma receita caseira para se aplicar na parede do antigo cine" (TJ/SC, 2016, p.211).

\footnotetext{
${ }^{6} \mathrm{O}$ engenheiro civil que assinou a ART (Anotação de Responsabilidade Técnica) do serviço foi Anderson Leite (TJ/SC, 2016, p. 107).
} 
Em novembro de 2004, a FCJ foi averiguar a situação do prédio do antigo Cine Palácio locado pela Igreja Universal, no qual propôs que houvesse uma vistoria técnica por engenheiro qualificado para avaliar as estruturas físicas do prédio, que veio recebendo modificações desde o início das obras, o que ocorreu algumas semanas depois. E, de fato, após essa vistoria técnica foi constatado que realmente houve modificações estruturais que dificilmente poderiam retornar ao original ou, pelo menos, à data do tombamento. Nesse mesmo ínterim, saiu a decisão do Tribunal de Justiça referente à liminar agravada pela Universal, decidindo que "a locatária realizou reformas urgentes, mas deveria ter consultado o órgão municipal responsável, a Comphaan" e que "realizou reformas constantes no projeto que ultrapassam a necessidade urgente de possível desabamento" (TJ/SC, 2016, p. 243-251).

Em maio de 2005, houve uma audiência entre membros do Ministério Público, membros da Fundação Cultural de Joinville e a Empresa de Cinemas Arcoíris Ltda. Durante a audiência, ficou clara a necessidade de um projeto de restauro para o prédio, bem como nova vistoria para se averiguarem as alterações que foram inseridas na edificação. Ainda nessa reunião, ouviram-se os inquilinos das outras salas laterais ao prédio principal, onde hoje é a igreja. Numa das oitivas, o proprietário de uma lanchonete que fica ao lado da entrada principal da Universal se manifestou dizendo que trabalhava ali desde 1977 e que ele seria o mais antigo inquilino de todo o prédio e afirmou ainda que viu as várias alterações que tinham sido feitas no edifício com os passar dos tempos.

Em paralelo à ação da Prefeitura contra o proprietário e o locatário do edifício do antigo Cine Palácio, a 14ạ Promotoria ajuizou, em 30 de março de 2006, uma Ação Civil Pública (ACP), por meio da Promotora Pública Thais C. Scheffer, em face da IURD, Empresa Arcoíris, Prefeitura Municipal de Joinville e Fundação Cultural de Joinville. Essa ACP, advinda do Processo Administrativo Preliminar no 54/2004/14a PJ, entrou em conexão com o processo de 2004 por se tratar das mesmas partes e do mesmo objeto de ação, o que significa dizer que ambos os processos iriam caminhar juntos até a decisão final.

Nas alegações da ACP, a Promotora afirmou que era desfavorável às obras realizadas pela Universal, principalmente porque não foram somente reformas emergenciais e por ter "exterminado parte da originalidade do bem cultural, o que deve gerar a devida e compatível compensação" (TJ/SC, 2016, p. 264). Além disso, a Promotora expôs que houve descaracterização do bem e, portanto, compete reparação de danos materiais e morais por parte dos responsáveis do imóvel, bem como a municipalidade e a FCJ devem responder por sua omissão frente ao descaso (TJ/SC, 2016, p. 283). Em junho de 2006, a Procuradoria Geral do 
Município requereu ao juiz da causa que a Fundação Cultural realizasse nova vistoria no prédio do antigo Cine Palácio, o que foi deferido na decisão judicial do juiz Carlos Adilson Silva. Após a vistoria, acompanhada de arquitetos da FCJ e engenheiros da Universal, a igreja juntou ao processo um laudo técnico atestando a ausência de risco a terceiros das instalações do prédio.

Dentro do prazo legal (julho de 2006), a Universal apresentou sua contestação à ACP, alegando reiteradamente que não houve alterações na fachada do prédio, apenas substituições de madeiramento interno e troca de telhas, a fim de evitar desabamento. Afirmou ainda, na contestação, que a Promotoria estaria querendo "restituir o irrecuperável". No sentido reverso, a Empresa Arcoíris, em setembro de 2006, juntou sua contestação, alegando que concordava com as considerações do Ministério Público e com o juiz que concedeu a antecipação de tutela para bloquear as obras de reparação do prédio (TJ/SC, 2016, p. 785). O proprietário do edifício e o locatário não estavam se entendendo muito bem, uma vez que apresentaram alegações completamente divergentes.

Na reunião da Comphaan de julho de 2006, Dietlind Clara Rothert informou a possibilidade dos administradores da Igreja Universal comprarem um terreno no centro da cidade para construir um novo templo. Na reunião, "sugeriu-se que os administradores comprem o Cine Palácio, restaurem a parte externa, hall de entrada e entorno e tendo liberdade de modificar a parte interna". Tal sugestão foi aprovada, desde que houvesse a elaboração de parecer técnico e documento explicitando os direitos e os deveres entre as partes, apresentando tal ato ao juiz da causa [Ata Comphaan, 12 jul. 2006]. Questiona-se: O que teria surtido aquela atitude da Universal em querer sair do prédio do antigo Cine Palácio? Talvez a falta de parceria reconhecida nos autos da ação civil pública por parte da proprietária do edifício, que afirmou categoricamente concordar com a Promotoria.

Ao fim daquele ano de 2006, a Prefeitura de Joinville e a Fundação Cultural tinham sido citadas e, portanto, apresentaram sua defesa (março de 2007) na ACP impetrada pela 14ạ Promotoria. A Prefeitura, por meio de seus Procuradores Municipais, alegou não ter havido omissão por parte do poder público municipal, assim como a Fundação, no mesmo sentido, reiterou as afirmações da Prefeitura e ainda juntou em sua defesa um parecer técnico assinado pelo coordenador da CPC, o arquiteto Raul Walter da Luz, em que constava a situação do edifício atualmente e todas as ações (Auto de infração, embargos e multas) da Fundação desde a notícia das alterações não autorizadas.

Após a juntada das contestações da Prefeitura e da FCJ, a Empresa Arcoíris juntou nova defesa, protegendo, em suas alegações, as atitudes da Universal. A impressão que nos passou 
esta atitude é que houve algum acordo, alguma negociação entre as partes, proprietário e locatário do edifício, para que realizassem a defesa sob os mesmos argumentos. A partir das fls. 851 dos autos, a Arcoíris alegou que as reformas realizadas foram indispensáveis para a manutenção física do prédio; que o direito à propriedade protegeria os seus possuidores de fazer o que bem quisessem com o bem em questão para mantê-lo em boas condições de uso; e que as obrigações advindas do tombamento não se misturam com a obrigação de manter o prédio habitável, não ocorrendo, dessa forma, qualquer dano a ser ressarcido ou compensado (TJ/SC, 2016, p. 851 sgts).

Em maio de 2007, a Promotoria protocolou sua réplica a todas as defesas juntadas desde as citações. Nesse documento, que se inicia às fls. 887, a Promotora alegou que tanto a Prefeitura quanto a Fundação não tomaram todas as medidas cabíveis à preservação do edifício, mas não indicou naquela oportunidade o que mais poderia ter sido feito, apenas enfatizando a omissão. Entendeu também que a empresa Arcoíris é corresponsável nas ações da Universal, que a igreja reformou o prédio e não o restaurou como devia e, portanto, é responsável pela restituição ao status quo da estrutura alterada, bem como deve restituir a sua originalidade frente ao dano irrecuperável, devendo pagar pelos danos morais coletivos e multa (TJ/SC, 2016, p.887).

Após a data de juntada da réplica, o assunto da judicialização do cine-teatro é pauta da Comphaan, agora sob o pretexto de que o Ministério Público Estadual tinha requerido uma reunião entre a FCJ e os representantes da igreja para discutirem o interesse de compra e a proposta de demolição do novo prédio espelhado, construído ao lado do edifício do cine [Ata Comphaan, 30 mai. 2007]. Não há nenhum documento sobre essa reunião nos arquivos em que se pesquisou, ficando a dúvida se ela realmente existiu ou não. O que se constatou, analisando as atas da Comphaan na continuidade da pesquisa, é que em junho de 2008 o coordenador da CPC, Raul Walter da Luz, informou que havia a possibilidade de venda real do edifício do antigo Cine Palácio para a Igreja Universal - informação que já havia sido ventilada há mais de um ano. Em contraponto, Raul Walter da Luz ainda afirmou que o edifício do antigo cine-teatro seria "local adequado para ser instalado o Teatro Municipal de Joinville. Questionando assim se teria interesse político e o que poderia ser realizado para a compra deste imóvel, a sra. Maria Cristina expõe que poderia ser direcionado pela apreciação da Comissão e ser recomendada a compra" [Ata Comphaan, 18 jun. 2008].

E foi o que ocorreu. A Comphaan, por meio da FCJ, encaminhou ofício à Prefeitura, sugerindo a compra pela municipalidade do imóvel em questão. Afinal, quando da construção 
do imóvel por Francisco Nicodemus, o dono do imóvel buscou incentivos fiscais afim de dar vida ao teatro municipal, embora mais tarde, o imóvel inaugurado sob o título de Theatro Nicodemus se tornou um espaço privado. A Prefeitura, em resposta, afirmou que não possuía recursos para tal empreitada.

\section{CONSTRUIR UM NOVO OU RESTAURAR O VELHO?}

Neste momento, faremos um aparte sobre a questão dos atores de pressão que desejavam a remoção da igreja para que o prédio voltasse a ser um cinema de rua ou então, um centro cultural. E iniciamos questionando quais são os critérios para se valorizar o que seria melhor para aquele espaço: Igreja ou cinema? O que está em jogo? Afinal, praticar a religiosidade também é um ato cultural. A fé mercantilizada para se entrar na igreja também era vista e debatida quando o cinema ali imperava. Só entravam os que pagavam o ingresso. Quem pode avaliar, sob o ponto de vista patrimonial, o que vale mais como cultura? Um cinema de rua ou uma igreja evangélica?

O Promotor Genivaldo da Silva (2016), em entrevista manifestou-se de modo crítico, questionando quem são as pessoas que desejavam o retorno do uso do edifício do antigo Cine Palácio à sua função de teatro e cinema.

O sagrado versus profano, que estavam no mesmo ambiente que mudou: De quem partiu essa ideia? Quem jogou essa ideia para fazer isso? Tem gente que tem uma ideia voltada para questão financeira, a pessoa tem uma ideia para questão econômica, a pessoa tem uma ideia da questão social, tem outra de sistema viário, outra voltado pelo saudosismo, 'meu tataravô veio assistir peças neste teatro, eu quero que volte a ser teatro', tem outro que tem ranço. Pode ser somente intolerância religiosa [informação verbal] ${ }^{7}$.

A noção de memória urbana ligada ao cine-teatro retoma uma Joinville sob o discurso de que só havia católicos, protestantes e maçons (que perambulavam em ambos os espaços, dependendo de suas crenças), ${ }^{8}$ não havendo lugar para nenhuma outra religião ou credo. A partir do uso do espaço pela Igreja Universal, o edifício do antigo cine serviu de invólucro para

\footnotetext{
7 SILVA, Genivaldo da. Genivaldo da Silva: entrevista [24 jun. 2016]. Entrevistadora: Christiane Heloisa Kalb. Florianópolis: Edifício da Promotoria Estadual, 2016. Entrevista concedida ao Projeto de Pesquisa Tese de Doutorado do Programa Interdisciplinar em Ciências Humanas, da Universidade Federal de Santa Catarina - UFSC. A entrevista na íntegra encontra-se transcrita no arquivo pessoal da pesquisadora/doutora.

${ }^{8}$ Digo perambulando porque a primeira loja maçônica estava localizada exatamente entre a paróquia católica e a sede da igreja luterana (KALB, 2013, p. 54).
} 
uma crença não muito bem aceita pela elite da cidade, pelo discurso de germânicos católicos e protestantes, em sua maioria. A ressignificação daquele espaço como espaço de credo neopentecostal feriu as crenças dominantes entre os antigos frequentadores do cine-teatro. Esse território é e foi um lugar de conflito de grupos, mas a partir da reapropriação por terceiros, os grupos hegemônicos reinantes até então se veem perdidos, hostilizados, prejudicados em meio a um uso sem memória e sem história. A solução vislumbrada foi o tombamento, como forma de tentar recuperar a representação simbólica e monumental germânica católica e/ou protestante daquele espaço cultural. A rejeição religiosa recebeu sua resposta por meio da patrimonialização.

A vontade de remoção da igreja de dentro do prédio parte da hipótese de que houve um desejo pela manutenção do cine-teatro, ainda que na forma de lugar de memória construído em meio às resistências, disputas, negociações, ressignificações, perdas de funções e invenção de outras. Em entrevista, Sandra Guedes (2016) fala sobre essas disputas quando o pedido de preservação do edifício do Cine Palácio foi recebido na Comphaan, especialmente quando se queria, no mesmo período, construir um teatro municipal na cidade:

As discussões surgiam em termos que a igreja estava impedindo que qualquer pessoa entrasse lá dentro, assim, só entravam os fiéis. Depois houve denúncias que a igreja estava descaracterizando a fachada e isto estava ocorrendo, não só na fachada, mas lá dentro também. E sendo um prédio superimportante para cidade, assim em termos de adesão, ao tombamento, que havia esses problemas de estar sendo descaracterizado. Houve um tempo, ainda que o prédio estava à venda, todo mundo sabia o preço, algo em torno de 3 milhões de reais. $E$ começou a ter estudos para a Prefeitura adquirir, não foi só a Comphaan que pressionava, isso era uma coisa que na cidade se falava. Na época, o Silvestre era o presidente da Fundação [Cultural] e havia uma proposta política de construir um novo teatro na cidade. Algumas pessoas concordaram, outras não, mas se já tínhamos o Cine Palácio que já foi um teatro, porque não colocar novamente o teatro ali, que foi a origem dele? Não porque a igreja não presta, mas porque havia a necessidade de fazer um teatro e aquele estava à venda. Por que a Prefeitura não adquire e não faz lá?, nos perguntávamos. E uma coisa que eu sempre reparei que aquele prédio teve a concepção original idêntica ao do Centreventos (Cau Hansen), porque era um centro cultural, ora era cinema, ora era patinação, ora era teatro, já teve até apresentação de circo, então ele era um centro de eventos [informação verbal] ${ }^{9}$.

9 GUEDES, Sandra P. L. de Camargo. Sandra P. L. de Camargo Guedes: entrevista [15 abr. 2016]. Entrevistadora: Christiane Heloisa Kalb. Joinville: Museu Nacional de Imigração e Colonização - MNIC, 2016. Entrevista concedida ao Projeto de Pesquisa - Tese de Doutorado do Programa Interdisciplinar em Ciências Humanas, da Universidade Federal de Santa Catarina - UFSC. A entrevista na íntegra encontra-se transcrita no arquivo pessoal da pesquisadora/doutora. 
Guedes afirmou que havia discussões em torno da impossibilidade de se adentrar no espaço por "qualquer pessoa que não fosse fiel". Nesse sentido, a historiadora não entendia o pedido de tombamento do edifício do antigo cine-teatro como uma resposta de uma elite germânica, mas sim, como um revide às descaracterizações arquitetônicas que a igreja locatária vinha realizando, fazendo alusão ao edifício espelhado que, em 2001, começou a ser ali construído ao seu lado. Por outro lado, Guedes, que deu início ao requerimento do tombamento do edifício do antigo cine junto ao engajamento de seus alunos, mostrou-se bastante favorável no sentido de questionar a necessidade de se comprar um novo espaço para construir um teatro, uma vez que o cine-teatro possuía toda a estrutura adequada para tanto. Apenas com algumas obras de restauro, o edifício do Cine Palácio poderia ser o novo teatro municipal da cidade. Lembrando que no início do século XX, quando Francisco Nicodemus enviou o projeto do Theatro para Prefeitura, o fez com a intenção de construir um teatro municipal, tanto que recebeu isenções de tributos para isso.

Genivaldo da Silva (2016) propõe alguns questionamentos sobre a construção de um novo teatro ou a mudança da igreja do edifício do antigo Cine Palácio para esse lugar tornar-se novamente teatro.

Isso poderia ser feito através de audiências públicas, teria muito mais legitimidade para desapropriar e poder comprar. Aquilo ali é da igreja, não é da Prefeitura. A Prefeitura simplesmente chegar, desapropriar e pagar [...]. Por que eles não pensam em fazer um teatro ali na antiga Prefeitura, na Max Colin, ali não serve para um teatro? Por que tem que ser ali? Qual é a capacidade? Nos anos 1920, 1930, quem ia assistir o teatro era um certo número de pessoas, e hoje, quanto precisamos? Na época poderia ter cadeira 'bem pertinho' uma da outra, hoje você já tem um INMETRO exigindo uma certa disposição, você tem cadeiras para pessoas obesas, para cadeirantes, tudo isso. Não seria mais interessante construir um outro teatro do que restaurar? São coisas que só o destino do Cine Palácio, seu presente, passado e futuro, dirão... [informação verbal]. ${ }^{10}$

A preocupação do Promotor de Justiça não deixa de ter sua importância. A estrutura de um teatro contemporâneo talvez não abrigue as mesmas condições que comportava no início do século XX. As disposições estruturais, como cadeiras, ventilação, projetos de som e imagem

10 SILVA, Genivaldo da. Genivaldo da Silva: entrevista [24 jun. 2016]. Entrevistadora: Christiane Heloisa Kalb. Florianópolis: Edifício da Promotoria Estadual, 2016. Entrevista concedida ao Projeto de Pesquisa Tese de Doutorado do Programa Interdisciplinar em Ciências Humanas, da Universidade Federal de Santa Catarina - UFSC. A entrevista na íntegra encontra-se transcrita no arquivo pessoal da pesquisadora/doutora. 
podem não estar dentro dos padrões hoje exigidos, o que poderia prejudicar a adequação restauradora do prédio do Cine Palácio, tornando-se inviável. Afinal, apesar das modificações internas implantadas pela igreja, como por exemplo, a retirada de cadeiras de madeira de marca Cimo, sendo substituídas por cadeiras de plástico, a substituição do forro de madeira no teto do teatro por forro plástico, a retirada do palco onde se realizava apresentações, substituído por um palco quase ao nível do chão, todas as alterações foram necessárias ao novo uso que se instalava. Provavelmente, estas mudanças também ocorreram por exigência do Corpo de Bombeiros, a fim de liberar um futuro alvará de funcionamento, mas aqui são apenas suposições.

Guilherme Gassenferth (2016), presidente da FCJ até dezembro de 2016, também respondeu a essa problemática levantada sobre Joinville ter atualmente somente um teatro municipal, e conclui:

Será que a gente é tão medíocre ao ponto de não ter um teatro para mil, 1.100 pessoas? Por que Joinville, na década de 1920, tinha teatro para 4 mil (sic!) pessoas e hoje mil lugares é muito? Eu acho que é um pensamento imediatista, é olhar para ocupação atual, daqui a dez anos vai ser outra cidade, aí vai ser muito pequeno" [informação verbal]. ${ }^{11}$

$\mathrm{O}$ antigo presidente da Fundação exagera, em certa medida, em relação à quantidade de pessoas que podiam adentrar no Theatro Nicodemus, que depois se renomeia Cine Palácio, dizendo que ali, no início do século XX, caberiam 4 mil pessoas. Por informações colhidas, o teatro comportava até mil pessoas. Por outro lado, Guilherme Gassenferth prediz que a cidade vem se modificando. E realmente não há como negar. O poder aquisitivo de algumas pessoas tem melhorado, apesar da crise financeira em que estamos vivendo. $O$ entretenimento tem sido uma das formas de lazer na qual as pessoas mais investem seu tempo e dinheiro. E em uma cidade sem praias $^{12}$, sem grandes praças e parques, os moradores de Joinville se dividem na hora do lazer entre as diversões urbanas (partidas de futebol e outros esportes, ir aos shopping centers, passear na via gastronômica e nos parques, como Zoobotânico, Parque Caieira e Parque da Cidade, frequentar espetáculos culturais, dentre outros) e rurais (trilhas, passeios na Estrada Bonita e em Pirabeiraba, e vários outros) que a cidade dispõe.

\section{A JUSTIÇA E O DIREITO NO CAMPO DO PATRIMÔNIO}

11 GASSENFERTH, Guilherme Augusto Heinemann. Guilherme Augusto Heinemann Gassenferth: entrevista [20 abr 2016]. Entrevistadora: Christiane Heloisa Kalb. Joinville: FCJ - 40 andar Centreventos, 2016. Entrevista concedida ao Projeto de Pesquisa - Tese de Doutorado do Programa Interdisciplinar em Ciências Humanas, da Universidade Federal de Santa Catarina - UFSC. A entrevista na íntegra encontra-se transcrita no arquivo pessoal da pesquisadora/doutora.

12 Há quem diga que o bairro da Vigoreli é uma praia, região que tem saída para a baía Babitonga. 
De volta à análise aos processos de nunciação de obra nova e ação civil pública, que estão conexos, observamos que em novembro de 2007 houve um pedido da Prefeitura de Joinville ao juiz da causa para que figurasse no polo ativo da ação civil pública, uma vez que assim figurava na ação de nunciação de 2004. Figurar no polo ativo significa alterar seu status de ré para autora na ação ao lado do Ministério Público. Contudo, a Promotoria negou tal pedido, argumentando que na ACP foi pedido à Prefeitura que ela restaure o bem em questão caso os responsáveis atuais do prédio não o façam, assim, atribuindo à municipalidade a condição de corresponsável. Fato previsto em norma legal que estipula as regras sobre responsabilidade sobre bem protegido, caso o proprietário não cumpra ou não possa cumprir com as obrigações legais de salvaguarda e manutenção do bem, a municipalidade deve arcar com tais restauros.

Na continuidade dos autos, o juiz da causa apresentou seu despacho saneador, em abril de 2008, quando se regularizaram as condições básicas da ação para uma futura audiência ou, se fosse o caso, uma decisão. E no caso in comento, o juiz entendeu necessário realizar perícia técnica sobre as condições físicas do edifício e marcou audiência em que seria ouvida a engenheira Silvania Miranda, perita indicada pelo juízo, sobre os quesitos do processo. Depois do despacho saneador, as partes juntaram seus quesitos e indicaram assistentes técnicos que participariam da audiência e da leitura do laudo técnico apresentado após a audiência pela engenheira Miranda.

Esses foram alguns dos quesitos apresentados pelas partes:

Quesitos resumidos da Prefeitura Municipal de Joinville.

1. Sobre o conjunto arquitetônico do Cine Palácio, ele possui relevância para a sociedade joinvilense? Essa relevância justifica o tombamento?

2. Com o tombamento, o imóvel perdeu sua utilidade?

3. O tombamento alterou a forma de uso do imóvel?

4. Houve descaracterização do imóvel antes do tombamento, quais?

5. Após a concessão da liminar de urgência, que paralisou as obras para conter um possível desabamento, houve descaracterização do prédio, quais?

Dentre várias outras perguntas. Observa-se pelas perguntas principais da PGM que a Prefeitura se preocupa em deixar esclarecido a situação de importância do edifício para a memória da cidade, problematiza o uso do espaço e ainda questiona possíveis descaracterizações. 
Quesitos resumidos da Igreja Universal do Reino de Deus, sendo que numa primeira oportunidade apenas perguntou sobre as obras realizadas e, depois, juntou novas perguntas.

1. Qual o documento que deu início ao processo de tombamento?

2. Segundo o Dossiê apresentado pela Univille, qual o aspecto arquitetônico que justifica o tombamento? Houve citação de alguma estrutura interna do prédio?

3. Segundo o documento de notificação, qual o aspecto arquitetônico que justifica o tombamento? Houve citação de alguma estrutura interna do prédio?

4. Segundo Parecer técnico do IPPUJ, qual o aspecto arquitetônico que justifica o tombamento? Houve citação de alguma estrutura interna do prédio?

5. Segundo a Comissão de patrimônio - Comphaan que sugeriu e votou pelo tombamento do prédio, qual o aspecto arquitetônico que justifica o tombamento? Houve citação de alguma estrutura interna do prédio?

6. A técnica do prédio é enxaimel? Este estilo é amplamente difundido na cidade de Joinville?

7. Os tijolos à vista no prédio em questão remetem ao estilo enxaimel?

E outras diversas perguntas que se referiam às obras realizadas após o tombamento, ferindo ou não uma possível autenticidade. Os quesitos da igreja abarcaram muitos assuntos, mas destacamos as que se referiam ao próprio procedimento de tombamento, ainda o questionando em sua validade, e também a ligação da arquitetura do edifício com um tipo especifico de construção que é bastante tradicional na cidade, o enxaimel. Os quesitos da Promotoria se referiam às obras e reformas feitas pela Universal, muito assemelhadas às perguntas das outras partes.

Desde o início do processo judicial de nunciação, em 2004, ocorreram diversas vistorias ao prédio e, em 2008, foi realizada uma reunião com a parte técnica da Fundação Cultural de Joinville e com os responsáveis do edifício, após a perita judicial ter apresentado sua sugestão de honorários periciais, que ficaram estabelecidos em $\mathrm{R} \$$ 11.360,00 (onze mil, trezentos e sessenta reais $)^{13}$, na qual discutiram-se detalhes de um futuro projeto de restauro, uma vez que a perita apenas apresentou seu laudo integral em 02 de agosto de 2010. E na ata da Comphaan de agosto daquele ano ficaram descritas as condicionantes dessa restauração:

[Raul] Informa que se realizou uma reunião de Subcomissão onde estavam presentes os representantes da Igreja Universal e os

\footnotetext{
${ }^{13}$ As partes envolvidas no processo dividiram as despesas relativas aos honorários periciais. A Prefeitura e a Fundação pagaram 50\% dos honorários e a igreja e a empresa Arcoíris pagaram o restante, cada uma $25 \%$.
} 
proprietários do Cine Palácio. [...] A Igreja possui o interesse de comprar o Cine Palácio, porém quer saber qual a posição da Comissão de Patrimônio. [...] deve-se considerar o nível de preservação volumétrica e a retomada da arquitetura original externa e também o acesso principal ao Cine Palácio, liberando-se a parte interna para que a Igreja possa estruturar conforme os seus critérios, desde que esteja de acordo com as leis. O processo hoje resgata o prédio no momento do tombamento, porém na época já existiam várias intervenções que o descaracterizavam, sendo assim não retoma a originalidade do imóvel. [...] A Igreja Universal se dispôs a resgatar a originalidade externa do prédio, para isso definiríamos os condicionantes do restauro e a partir de então, iriam ao Ministério Público realizar um Termo de Ajuste de Conduta, onde seguiriam um cronograma de execução [Ata Comphaan, 13 ago. 2008].

As tratativas se estenderam por meses e passados mais de meio ano, os representantes da igreja ainda não tinham iniciado as obras de restauro que prometeram naquela reunião na FCJ, pois até o momento não havia decisão judicial que homologasse tal acordo extrajudicial. Quando a perita apresentou seu laudo, um documento com mais de 200 laudas contendo uma breve historicização do prédio, com plantas, fotos, notícias e recomendações, respondeu a todos os diversos quesitos das partes. De modo conciso resumo o que a perita argumentou: que o edifício do Cine Palácio possui relevância até hoje, vez que é mencionado em vários livros de história da cidade; que não perderia sua utilidade se usado pela Igreja Universal, pois até hoje uma das outras salas laterais do prédio é usada também por um bar desde 1977, assim como há outros usos sendo feitos atualmente; que o prédio é visto como um centro de convivência social com manifestações culturais diversas até os dias atuais; que seu estilo é neoclássico e, portanto, não é estilo enxaimel, mas faz referência ao enxaimel após a alteração observada, que foi aplicada pela conveniência de não necessitar pintar sempre e evitar problemas de infiltração. A perita entendeu ainda que a igreja não teve intenção de prejudicar o edifício e descaracterizá-lo. E finalizou a argumentação dizendo que não há hoje uma estrutura que se possa chamar de original ou autêntica, tendo em vista todas as diversas alterações estéticas e estruturais que se fizeram desde a sua inauguração, em 1917 (TJ/SC, 2016, fls 1020 - ssgts).

A seguir, veem-se três imagens (figs. 2 - 4) que mostram a sequência das alterações arquitetônicas e estéticas do edifício principal do antigo Cine Palácio. A fonte dessas imagens encontra-se também no laudo pericial apresentado em 2010 pela engenheira Silvania Miranda (TJ/SC, 2016, p. 1038-40) no processo judicial iniciado no ano de 2006.

Figura 2: Edifício principal - Theatro Nicodemus, 1917. 


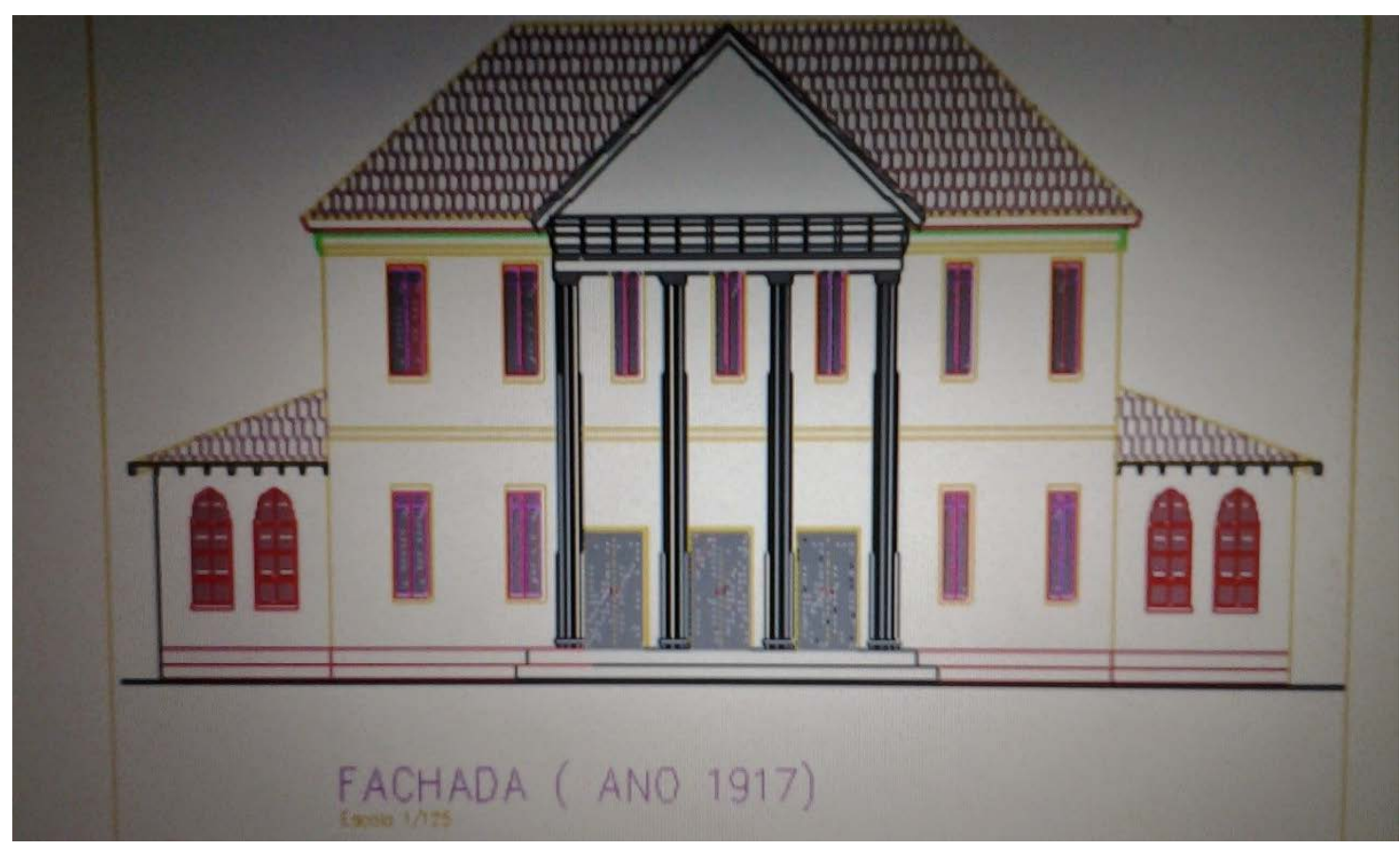

Fonte: Análise e vistoria de imóveis tombados em Joinville - SC. XVII COBREAP - Congresso Brasileiro de Engenharia de Avaliações e Perícias - IBAPE/SC. Disponível em: <www.cobreap.com.br/2013/trabalhosaprovados/2884.pdf>. Acesso: jul, 2016, p. 13, 2013.

Da figura 2, em comparação à figura 3, observa-se a construção de um acréscimo de pavimento térreo, ao lado esquerdo do prédio, e outro acréscimo de pavimento com um andar na continuidade da edificação original, ao lado direito, obra que se realizou nos anos 1970. Além disso, na imagem do início do século (1917) não havia a configuração estética de tijolos à vista, assim, as paredes frontais do edifício eram apenas pintadas com tinta, sem nenhuma textura. Após a colocação das pastilhas sobre a pintura básica da fachada, a estetização de tijolos imitou o estilo enxaimel, com intento de evitar sucessivas pinturas e uma menor manutenção. Ainda de acordo com o laudo pericial constante nos autos da ACP - Ação Civil Pública, em 1959 houve uma grande reforma no prédio, aprovada pela Prefeitura de Joinville, realizada pela empresa Van Biene (antiga proprietária, após a Família Nicodemus ter vendido o imóvel), por meio dos serviços da Keller e Cia. (TJ/SC, 2016, p. 1066).

Da versão de 1978 para a atualidade, foi acrescido ao edifício um andar ao acréscimo do lado esquerdo do prédio e ainda, ao lado desse mesmo acréscimo, no entorno imediato foi construído, colado ao edifício principal, um prédio espelhado com colunas circulares, já mencionadas acima.

Figura 3: Edifício principal com alterações, Cine Palácio, 1978. 


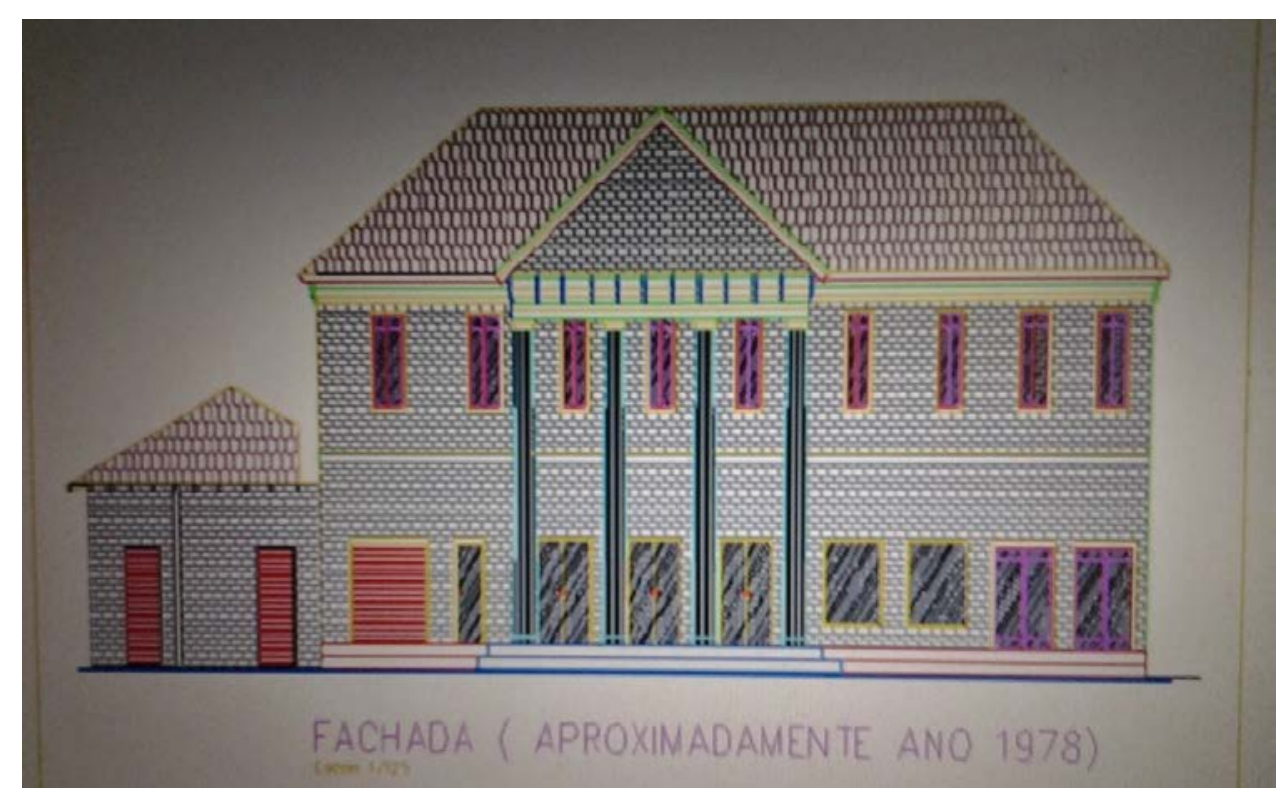

Fonte: Análise e vistoria de imóveis tombados em Joinville - SC. XVII COBREAP - Congresso Brasileiro de Engenharia de Avaliações e Perícias - IBAPE/SC. Disponível em: <www.cobreap.com.br/2013/trabalhosaprovados/2884.pdf>. Acesso: jul, 2016, p.13, 2013.

Figura 4: Edifício principal, construção contemporânea, 2014.

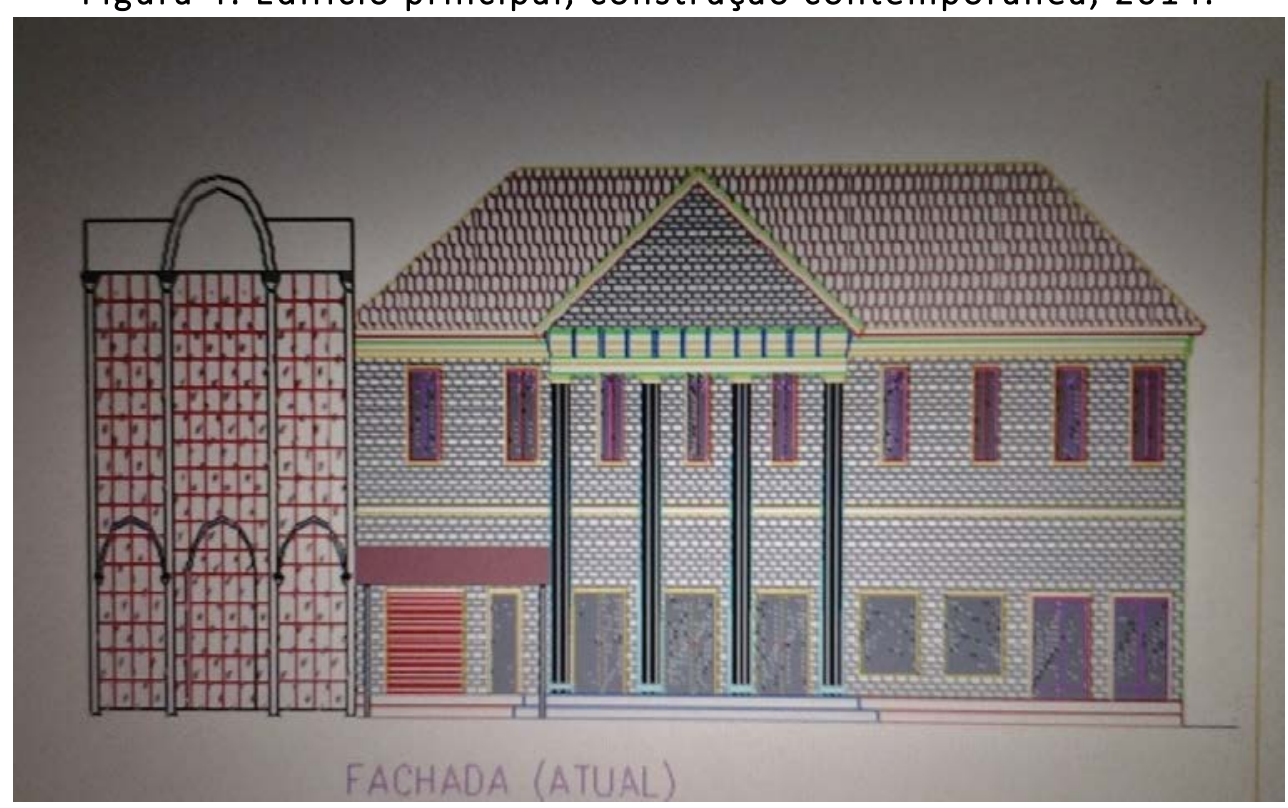

Fonte: Análise e vistoria de imóveis tombados em Joinville - SC. XVII COBREAP - Congresso Brasileiro de Engenharia de Avaliações e Perícias - IBAPE/SC. Disponível em: <www.cobreap.com.br/2013/trabalhosaprovados/2884.pdf>. Acesso: jul, 2016, p. 13, 2013.

Desde o início do processo judicial, os técnicos vinham tentando de todas as formas adentrar no edifício para acompanhar as alterações estruturais e estéticas que foram se realizando no lugar, mas ainda sofriam com a dificuldade em poder acessar o interior do prédio. A notícia dessas alterações chegava aos ouvidos dos membros da Comphaan por meio de boatos, nada formal, nada documentado. 
Em março de 2012, a Defesa Civil requereu ao representante da igreja a substituição da placa de comunicação visual do prédio, por razões de risco de queda. Pedido esse repassado ao juiz da causa em andamento que autorizou a modificação, desde que autorizada pela Comphaan. O pedido foi enviado à decisão da FCJ no dia 15 de março do mesmo ano e a substituição da placa foi aprovada pela Comissão do Patrimônio. Na figura 5 observa-se como era a placa em frente à fachada do edifício: uma enorme placa branca, ocultando parte das colunas do edifício, com o nome Jesus Cristo é o Senhor; e como seria a proposta, apenas com o nome da igreja no triângulo, onde no início do século XX havia uma imagem de uma lira com o nome Theatro Nicodemus.

Figura 5: Fachada do antigo Cine Palácio, 2011.

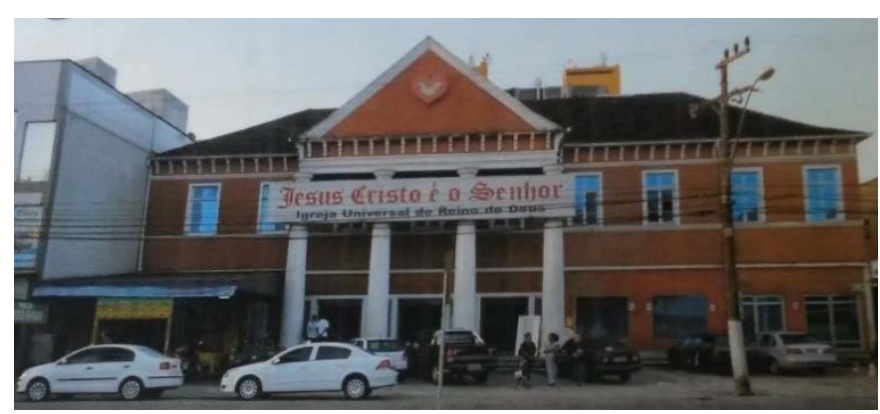

Fonte: FCJ, 2002, p.

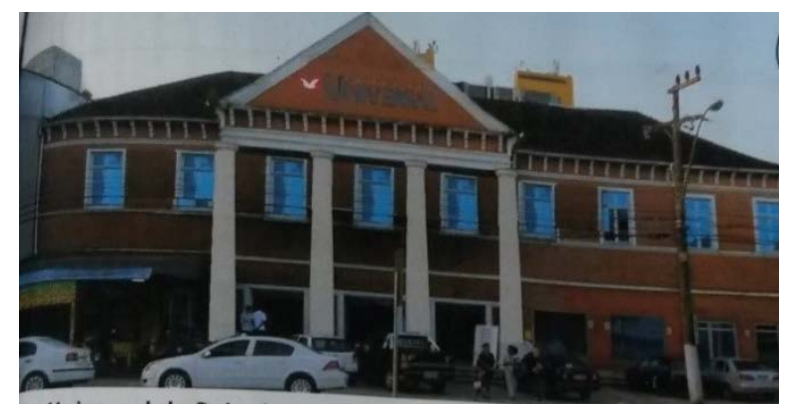

352-353.

Em

Igreja Universal,

imóvel, fez novo

para realizar algumas

2013, a ainda locatária do requerimento à $\mathrm{FCJ}$ reformas de pintura e aplicação de impermeabilizante na fachada do prédio. A Comphaan, em deliberação, no mesmo mês aprovou o pedido, porém, ainda lembrando que as alterações estruturais realizadas no início dos anos 2000 não tinham sido restauradas. Quase um ano se passou e, em 14 de maio de 2014, finalmente a sentença judicial da 2a vara da Fazenda Pública da comarca de Joinville, 
dada pelo juiz Roberto Lepper, foi publicada ${ }^{14}$ para ambos os processos, a nunciação de obra nova e a Ação Civil Pública.

De acordo com a decisão, a Fundação Cultural de Joinville deveria, em 120 dias, elaborar - Plano de Obras a ser efetivado para a restauração das características originais do imóvel, considerando as atuais condições do prédio ${ }^{15}$ e as sugestões ofertadas no laudo técnico apresentado em juízo. A decisão ainda proibiu a Igreja Universal (locatária) e a Empresa Arcoíris (proprietária) de realizarem qualquer alteração do prédio sem prévia anuência da Fundação; obrigou-as a liberarem o acesso aos servidores do Município de Joinville e da Fundação Cultural às dependências do prédio tombado; e condenou-as, solidariamente, a efetivarem em até oito meses as medidas sugeridas pela Fundação, sob pena de multa no importe de $\mathrm{R} \$ 10.000,00$ (dez mil reais) por mês caso houvesse o descumprimento.

Analisando a sentença, praticamente idêntica para ambos os processos, o juiz da causa dá sinais de afeto e identificação com o espaço cinematográfico. Senão vejamos como descreveu o douto magistrado do processo as suas lembranças:

Os cinemas se popularizaram e Joinville não ficou fora dessa onda. $\mathrm{Na}$ década de setenta, os cines Colon e Palácio disputavam a preferência do público, que lotaram suas salas para verem superproduções holiwoodianas. No "CinePalácio", trajando uma cacharrel que minha mãe achava que me deixava vistoso, assisti "Star Wars", "Tubarão II", "Aeroporto 77", "Alien, O 80 Passageiro" e "Embalos de Sábado à Noite", não necessariamente nessa ordem. Lembro ainda que, na exibição de "ET, O Extraterrestre", em 1983, assisti o filme sentado no chão porque a sala estava completamente lotada (TJ/SC, 2016, p.1272 sgsts).

Assim, na sentença, especialmente da ACP, ficou claro o posicionamento do magistrado, que afirmou categoricamente que a Universal deveria ter tomado as medidas preventivas antes de chegar a um possível risco iminente, afinal, já era detentora do espaço desde início dos anos 1990. Por isso, no entendimento do juiz, a locatária agiu com desídia e deve ser responsabilizada, com base no princípio da responsabilização do poluidor-pagador/causadorpagador, previsto na legislação ambiental, que se insere no arcabouço jurídico de preservação do patrimônio cultural. Além disso, na sentença, o juiz julgador refere-se às alterações do

\footnotetext{
${ }^{14}$ Em 2008, o processo de 2004 (ação de nunciação) foi para o gabinete do juiz Carlos Adilson Silva, que comandava a 1a vara da Fazenda Pública da comarca de Joinville. De 2008 até 2012, o processo ficou relativamente 'parado'. Em 2012, foi realocado para a 2a vara da Fazenda pública. Digo parado pois a ACP de 2006 praticamente se tornou processo principal frente à força do Ministério Público na ação, até que ambas as ações, em maio 2014, foram julgadas pelo juiz Roberto Lepper.

${ }^{15} \mathrm{Em} 06$ de agosto de 2014, a Igreja Universal entrou com Embargos de Declaração a fim de esclarecer se deveriam recompor as condições originais do edifício de 17 de abril de 2002, quando iniciou o processo de tombamento, ou as condições ditas originais desde 1917. O juiz da causa decidiu pela primeira opção.
} 
espaço tombado em debate como impactantes à originalidade do prédio e manda serem desfeitas na medida do possível, restituindo ao Cine Palácio sua originalidade. Nesse sentido, o magistrado nega a condição de irreversibilidade dos danos causados à estrutura e cita o laudo pericial que concluiu pela possibilidade de retorno ao status quo do edifício quando inaugurado, em 1917.

A IURD teve reconhecido alguns pedidos a seu favor, como por exemplo, restaurar o prédio nas mesmas condições da data da notificação do tombamento, ou seja, maio de 2002 e não desde 1917, quando inaugurado. E também ficou configurada a responsabilidade subsidiária: caso a Universal e a Empresa Arcoíris não cumpram com a determinação judicial, a Prefeitura e a Fundação Cultural assumirão para si a obrigação de restaurar o bem tombado. Isso significa também dizer que todas as alterações arquitetônicas e estéticas que se realizaram no prédio até a data do seu tombamento, em 2003 teriam que ser incorporadas à nova realidade do edifício e não mais poderiam ser reclamadas na Justiça. Essa questão foi apresentada na reunião da Comphaan [Ata Comphaan, 16 mar. 2016], em que ficou esclarecido que o proprietário terá que retomar a fachada principal (algumas aberturas e comunicação visual) e algumas poucas alterações no interior do prédio. No entanto, são alterações de menor monta, se comparadas com os pedidos iniciais da Fundação Cultural, que tinha requerido o retorno da arquitetura do prédio desde quando iniciou as primeiras alterações, no fim da década de 1990, a partir da locação do espaço pela igreja.

\section{CONSIDERAÇÕES FINAIS}

Após mais de dez anos de conflitos judiciais e extrajudiciais, a preservação e a necessidade de restauração venceram juridicamente em primeiro grau as atitudes realizadas pelo proprietário e pela locatária. Em novembro de 2014, a Fundação Cultural cumpriu com o prazo estipulado pelo douto magistrado e apresentou, perante o município e se dirigindo ao proprietário e à locatária, a prévia do Plano de Obras para o edifício do antigo Cine Palácio (FCJ, 2002, p. 683-730). Porém, ele não foi plenamente aceito pela Procuradoria do Município, que em razão dos embargos impetrados pela Igreja Universal e pela empresa Arcoíris, com pedido de aclaramento de algumas questões judiciais, teve seu prazo de entrega final do Plano de Obras modificado para o dia 06 de maio de 2015. A Prefeitura apresentou o novo Plano de Obras de Restauro com relatório fotográfico dentro do prazo. Contudo, o proprietário recorreu 
da decisão de 10 grau à 2a instância, para que decisão fosse decidida por um colegiado, no Tribunal de Justiça, em Florianópolis.

Em 19 de janeiro de 2015, a Igreja Universal ajuizou Recurso de Apelação pedindo a reforma da sentença de 1으 grau. Em suas alegações ficou clara a reiteração dos pedidos que fizeram nas defesas dos dois processos, no sentido de declarar as obras realizadas como emergenciais para evitar qualquer risco em razão do estado de possível desabamento, de afirmar que as reformas não prejudicaram o prédio em si e que a reforma em si preservou mais ainda o bem tombado, uma vez que se agiu em boa fé. Em fevereiro, a empresa Arcoíris também apelou requerendo o afastamento da responsabilidade solidária, especialmente quanto às obras apontadas no Plano de Obras, que deveriam, a seu ver, serem assumidas integralmente pela Universal, que iniciou a reforma sem autorização do órgão responsável. Percebe-se, pela apelação da Arcoíris, que houve novo embate com a Universal, uma vez que a proprietária foi considerada tão responsável pela condenação quanto a igreja, que efetivamente realizou as obras ditas emergenciais, consideradas indevidas pela sentença de 1 으 grau.

Em março de 2015, o desembargador responsável pela análise do recurso decidiu pela aplicação apenas do efeito devolutivo, negando o efeito suspensivo. Isso significa que alguns dispositivos concedidos na sentença pelo juiz de Joinville já poderiam ser executados e, dessa forma, exigidos a sua efetivação e o seu cumprimento. E o efeito devolutivo, quer dizer, que se devolve, levando a decisão ao Tribunal a um colegiado de doutores conhecedores do assunto. Em setembro, a Universal agravou a decisão do desembargador e pediu a efetivação do efeito suspensivo, para que nenhum dispositivo da sentença de Joinville tenha validade até se decida definitivamente no Tribunal.

Em abril de 2016, a Promotoria se manifestou pela não concessão dos pedidos suspensivos e devolutivos da igreja. Antes de decidir definitivamente quanto aos efeitos ligados ao recurso, em 10 de junho de 2016 o desembargador Paulo H. Moritz requereu informações à FCJ quanto a possíveis novas reformas no edifício do antigo Cine Palácio. Em resposta, a FCJ informou, por meio de seu presidente da época, Guilherme Gassenferth, e Anne Elise (funcionária pública lotada na FCJ) (TJ/SC, 2016, p. 1502) que a Universal teria feito manutenções preventivas no espaço. Indicou, então, interditar o local e realizar um novo laudo estrutural da cobertura do edifício, particularmente quanto à estabilidade da estrutura, e ainda afirmou que a igreja precisa se regularizar na Prefeitura, pois ainda não detém alvará de funcionamento. 
Mais recentemente, o Ministério Público, instado a responder ao Oficio da Fundação Cultural, argumentou, por meio de manifestação datada de 06 de agosto de 2016, que o documento apresentado pela FCJ estava impreciso e inconclusivo, pois demonstrava evidentemente a conduta desidiosa de todos os órgãos envolvidos na proteção do patrimônio da cidade de Joinville. A Fundação, de acordo com a Promotoria, aguardou mais de um ano para receber algum parecer da Defesa Civil quanto a um possível perigo de desabamento do imóvel e não tomou nenhuma medida, nem demonstrou proatividade, para evitar prejuízos aquele patrimônio. Por essas razões e por novamente alegar que as obras ditas emergenciais realizadas pela Universal em meados dos anos 2000 e também após a decisão de 1o grau não passaram pelo crivo da Fundação, descumprindo os limites da sentença impostos aos réus, a Promotoria reiterou pelo indeferimento do pedido de concessão do efeito suspensivo da apelação protocolada em janeiro de 2015. Após a juntada da manifestação do Ministério Público, em 08 de setembro de 2016, os nove volumes de processos foram encaminhados ao Desembargador Relator para sua conclusão e lá permanecem até hoje ${ }^{16}$.

No processo judicial não se discutiu o sentimento de pertencimento das pessoas que no cine-teatro usufruíram de momentos nostálgicos, mas nota-se, pelas palavras do corpo técnico da Fundação, quando entrevistados, um sentimento de fracasso numa tentativa de resgate de algo perdido: o cinema perdido, uma memória talvez perdida. Durante o processo administrativo há o pedido direto da Fundação ao prefeito para que adquira tal imóvel, por meio de desapropriação indireta, realizando, quem sabe assim, o desejo reprimido dos agentes do campo do patrimônio da cidade em ver o cinema ressurgir das cinzas. Isso também aconteceu agora, recentemente, quando se discutiu esse assunto com o antigo presidente da FCJ, Guilherme Gassenferth, que disse categoricamente que se permanecesse no cargo após as eleições de 2016 levaria a questão do edifício do antigo cine-teatro às mãos do prefeito Udo Döhler (PMDB), reeleito. Ele não permaneceu no cargo, apesar de ter sido transferido à gerência de patrimônio da FCJ.

A judicialização desse embate colocou entraves resistentes de ambos os lados: a Igreja Universal, locatária do imóvel, viu-se obrigada a realizar obras emergenciais no prédio para que não desabasse por cima de seus fiéis. Contudo, não tomou as medidas legais necessárias,

\footnotetext{
${ }^{16}$ Conversamos com o assessor do desembargador Paulo H. Moritz, em 19/09/2016 em seu gabinete no Tribunal de Justiça, Torre 1, 1 andar, sala 105, que informou não haver prazo para julgar este recurso impetrado pela Universal contra a decisão do juiz de Joinville. Observando a pilha de processos onde se encontro os autos da judicialização do caso do Cine Palácio, trata-se de mais de 200 processos a serem julgados, na mesma situação que os autos em análise.
} 
descumprindo os limites do tombamento, pois realizou alterações sem o aval da Fundação e da Comphaan; a Empresa Arcoíris, proprietária do imóvel, demonstrou, à primeira vista, um total desconhecimento das atitudes de sua locatária, o que, por ser corresponsável na preservação, Ihe geraria consequências de qualquer forma, sabendo ou não da existência das obras; e a Prefeitura e a Fundação Cultural parecem, ao ver da Promotoria, terem se omitido frente às ações da Universal, já que são as entidades responsáveis pela fiscalização e preservação do patrimônio da cidade.

Portanto, ainda não se tenha uma solução definitiva sobre esse caso paradigmático de patrimônio em que o tombamento não salvou o bem em si, mas gerou consequências dentro do campo do patrimônio que só o Direito poderia solucionar. É um caso que se vê permeado pelas mesmas categorias analíticas de quando se discute a possibilidade de preservação versus destruição, da proteção do passado versus a chegada da modernização e da escolha do Estado de fazer ou não fazer.

\section{REFERÊNCIAS}

ANDERSON, B. Comunidades imaginadas: reflexões sobre a origem e a difusão do nacionalismo. Tradução de Denise Bottman. São Paulo: Companhia das Letras, 2008.

A carta de Atenas. (1933) Trad. Rebeca Sherer. São Paulo: Hucitec/Edusp, 1993. (Estudos Urbanos), $38 \mathrm{p}$.

BRASIL. Constituição (1988). Constituição da República Federativa do Brasil. 40 ed. São Paulo: Saraiva, 2007.

FCJ. Atas das reuniões da COMPHAAN. Reuniões da Comissão de Patrimônio. Joinville: Fundação de Cultura de Joinville, anos 1980 a 2013 - Livro Ata.

Atas das reuniões da COMPHAAN. Reuniões da Comissão de Patrimônio. Joinville: Fundação de Cultura de Joinville. 2014.

Atas das reuniões da COMPHAAN. Reuniões da Comissão de Patrimônio. Joinville: Fundação de Cultura de Joinville. 2015.

Atas das reuniões da COMPHAAN. Reuniões da Comissão de Patrimônio. Joinville: Fundação de Cultura de Joinville. 2016.

Processo de Tombamento FCJ/CPC n 2002-001 A-F do Cine Palácio. Joinville: Fundação Cultural de Joinville, 8 volumes, 2002.

GASSENFERTH, Guilherme Augusto Heinemann. Guilherme Augusto Heinemann Gassenferth: entrevista [20 abr. 2016]. Entrevistadora: Christiane Heloisa Kalb. Joinville: FCJ - 40 andar Centreventos, 2016. Entrevista concedida ao Projeto de Pesquisa - Tese de Doutorado do Programa Interdisciplinar em Ciências Humanas, da Universidade Federal de Santa Catarina UFSC. A entrevista na íntegra encontra-se transcrita no arquivo pessoal da pesquisadora/doutora. 
GONÇALVES, J. R. S. Antropologia dos objetos: coleções, museus e patrimônios. Rio de Janeiro: Ministério da Cultura, IPHAN, 2007.

GUEDES, Sandra P. L. de Camargo. Sandra P. L. de Camargo Guedes: entrevista [2016]. Entrevistadora: Christiane Heloisa Kalb. Joinville: Museu Nacional de Imigração e Colonização MNIC, 2016. Entrevista concedida ao Projeto de Pesquisa - Tese de Doutorado do Programa Interdisciplinar em Ciências Humanas, da Universidade Federal de Santa Catarina - UFSC. A entrevista na íntegra encontra-se transcrita no arquivo pessoal da pesquisadora/doutora.

HANDLER, Richard. On having culture. In: STOCKING, Georg (org) Objects and other: essays on museums and material culture. Madison, The Wisconsin University Press, 1985.

IPHAN. Portal do IPHAN. Disponível: <portal.iphan.gov.br/uploads/ckfinder/.../Recomendacao\%20de\%20Paris\%201962.pdf> Acesso: 15 jun 2017.

KALB, C. K. Patrimônio industrial: as memórias de ferramenteiros em Joinville, Joinville, Univille. Dissertação de Mestrado em Patrimônio Cultural e Sociedade, 186 p., 2013.

SILVA, Genivaldo da. Genivaldo da Silva: entrevista [24 jun. 2016]. Entrevistadora: Christiane Heloisa Kalb. Florianópolis: Edifício da Promotoria Estadual, 2016. Entrevista concedida ao Projeto de Pesquisa - Tese de Doutorado do Programa Interdisciplinar em Ciências Humanas, da Universidade Federal de Santa Catarina - UFSC. A entrevista na íntegra encontra-se transcrita no arquivo pessoal da pesquisadora/doutora.

TRIBUNAL DE JUSTIÇA DE SANTA CATARINA. 2a vara da Fazenda Pública da comarca de Joinville. Ação de Nunciação de Obra Nova cominada com demolitória e antecipação de tutela. Autos número 0021739-62.2006.8.24.0038. Prefeitura de Joinville, Procurador Municipal Luiz Bernando West Costa, em face da Igreja Universal do Reino de Deus e Empresa de Cinemas Arcoíris Ltda., 24 jun. 2004.

Ação Civil Pública. Autos número 0021739-62.2006.8.24.0038 / 038.06.021739-9. 14ạ Promotoria através da Promotora Thais Scheffer, em face da Prefeitura de Joinville, da Fundação Cultural de Joinville, da Igreja Universal do Reino de Deus e da Empresa de Cinemas Arcoíris Ltda., 30 mar. 2006.

UNESCO, ICOMOS, ICCROM. DOCUMENTO DE NARA sobre a autenticidade. Trad. Antonio de Borja Araújo. Disponível em: http://portal.iphan.gov.br. Cartas Patrimoniais. Acesso: maio 2016; 1994, 5 p.

RECOMENDAÇÃO DE NAIROBI - Recomendação relativa à salvaguarda dos conjuntos históricos e sua função na vida contemporânea - Nairobi: UNESCO (Organização das Nações Unidas para a Educação, a Ciência e a Cultura - 19a Sessão). In: IPHAN: Instituto do Patrimônio Histórico e Artístico Nacional (1995). CARTAS PATRIMONIAIS (cadernos de Documentos no 3) Brasília: IPHAN, 1976. P. 251-268.

Trabalho enviado em 19 de maio de 2017.

Aceito em 16 de outubro de 2017. 